\title{
REGULATORY AND MODIFYING ROLE OF NATURAL POPULATIONS OF ENTOMOPHAGES IN BIOCENOSES OF THE EXCLUSION ZONE OF THE CHERNOBYL NUCLEAR POWER PLANT
}

\section{Drozda Valentin*, Bondarenko Ilona, Zagayko Olga}

National University of Life and Environmental Sciences of Ukraine, Kyiv, Ukraine

The level of regulatory and modifying role was estimated on example of ecological and trophic interactions of population of aphids and their entomophages - Aphidiidae and Aphelinidae. Long-term researches (1986-2012 years) were conducted in biocenoses of the exclusion zone of the Chernobyl nuclear power plant. This is primarily, woody and shrub plants, including fruit crops. Seasonal monitoring of aphid populations was carried out by known methods in entomology and parasitology. Regular collections are provided for subsequent identification of aphid species. The level of infection of different stages by parasites was determined in laboratory conditions. The species composition and level of predation were established. The level of regulation of aphids from side of entomophages was determined. This process was evaluated on the basis of statistical materials and biocenotic role of zoophages. The life strategies of aphids and their entomophages were formulated. The researches were carried out by route surveys of habitats and ecosystems in spring, summer and autumn periods and regular observations and counts of entomological populations in nature, followed by laboratory and field experiments. As result of conducted researches were found 9 species of aphids on plants of Rosaceae family. We have established that most of them prone to r-selection with accent on tactics of reproduction and trophic connections. The character and specificity of settlement of aphids on plants were identified. Their trophic specialization with respect to different organs of plants was determined. The character of harmfulness of larvae and aphid adults was investigated in detail. We have established that significant quantity of entomophages with population of aphids ecologically and trophically are associated, mainly various predators: ladybird beetles (Coccinellidae), Syrphidae, gall midges (Cecidomyiidae) and Chrysopidae. The types of functional reaction in system «aphids-aphidophages» were investigated. Modifying role of aphidophages in dynamic of strength of population of aphids was shown. Authors of this article have established that Aphidiidae are manifesting elements of regulatory role sporadically, parasitizing on insignificant part of effective population of aphids.

Keywords: aphids of woody plantings; Aphidiidae; Aphelinidae; functional reaction; regulatory and modifying role

\section{Introduction}

The ecosystems and former agrocenoses of the exclusion zone of the Chernobyl nuclear power plant function in regime of self-regulation for already more than 30 years. They are exchanging energy and information with various components of ecosystems as thermodynamically open systems. Essentially, it is gigantic natural laboratory for exploring many processes on population and organism levels.

*Corresponding author: Valentin Drozda, National University of Life and Environmental Sciences of Ukraine, Kyiv, Ukraine, $\triangle$ biomethod@quality.ua 
In our view, especially valuable from theoretical and practical side is exploring of mechanisms of «succesio» with use most objective and informative test characteristics. We are talking about complex interactions in triotrophic system with key role of indicators of dynamic of strength of arthropod.

As it is known, the energy flow in trophic chain is directed on the gradient of her dispersion. This vector has clear orientation, from autotrophs to phytotrophs and from phytophages to entomophages. The energy losses on each link of her transmission are 90-99\%. However, the most significant in this process and far from obvious is fact that the vector of management between components of ecosystem is similarly oriented (Стадницкий и Бортник, 1979; Дрозда и Гойчук, 2015; Дрозда, 2015a; Дрозда и Сагитов, 2015b).

This fundamental regularity has oriented the process of evolution of adaptations of living organisms to environmental factors. This means that from variety of scenarios the priority in strategy of development of adaptations between producents and consuments is owned by consuments, that is phytophages. Phytophages are controlled by plants completely, as trophic factor and also habitat for them in many cases.

Obviously, that such regularity has developed in the system of consuments of different level too. Judging by this logic, zoophages have developed adaptations not only to the hosts, but also to the fodder sources in process of evolution.

It is generally accepted in ecology that in systems "predator-prey» is observed cyclical process of mutual management of populations. They located on different levels of trophic chain. In this case, the homeostasis of system is supported alternating «inclusion» of positive and negative feedbacks. Such concept goes back to parasitic theory of the dynamic of populations. The outbreaks of mass reproduction occur due to «escape» of their populations out of control of entomophages.

\section{Materials and methodology}

Long-term researches (1986-2012 years) were conducted in biocenoses of the exclusion zone of the Chernobyl nuclear power plant. This is primarily woody and shrub plantings, including fruit crops. An essential feature was that all ecosystems were not subjected to any receptions of economic activity. Seasonal monitoring of aphid populations was conducted by known methods in entomology and parasitology. Regular collecting with following identification of aphid species was carried out. The level of infection by parasites of different stages was determined in laboratory conditions. The species composition and level of predation were established (Адашкевич, 1975; Дорохова и др., 1989). The level of regulation of aphids from side of entomophages was determined. This process was evaluated on basis of statistical materials and biocenotic role of zoophages. The life strategies of aphids and their entomophages were formulated (Яснош, 1975, 1975а, Варли и др., 1978).

The researches by way of route surveys of habitats and ecosystems in spring, summer and autumn periods, regular observations and accounts of entomological populations in nature and laboratory and field experiments were carried out. Identify of the species composition of entomofauna was implemented by way of manual collection on plants and entomological net. In each habitat were carried out 10 of mowing operations with 40 double swings, using entomological net. The species composition of parasites by collecting of mummified aphids and individually isolation of parasites from them in Florinsky test tubes was studied (Лахидов, 1978; Колесова, 1979). The exploring of ecology of aphids and aphidophages, biocenotic relationships between them was conducted traditional methodologies (Теленга, 1959; Скуфьин и др., 1962; Дядечко, 1978). 


\section{Results and discussion}

On plants of family of Rosaceae with prevalence of pome cultures were identified 9 aphid species. These are such species as green apple aphid (Aphis pomi Deg.), apple-grass (oat-apple) aphid (Rhopalosiphum insertum Walk.), rosy (apple) aphid (Dysaphis mali Ferr.), Ovatus insitus Walk., Dysaphis anthrisci C. B., Dysaphis reamuri Mordv., Schizaphis puri Shap., woolly pear aphid (Eriosoma lanuginosum Hart.), pear-hogweed (parsnip root) aphid (Anuraphis subterranea Walk.), rosy leafcurling aphid (Dysaphis devecta Walk.). These species are biologically heterogeneous. As it is known, according to type of life cycle they are divided into species with full cycle of development (monoecious, dioecious) and incomplete cycle. The typical representatives with monoecious life cycle are green apple aphid and rosy leaf-curling aphid.

Most fruit aphids develop by type of dioecious cycle. In biology of aphids developing in ecosystems of the exclusion zone has been noted nothing significant. They hibernate in stage of egg on fruit crops. «The founders» from eggs appear early in spring. They are developing in 2-4 and more generations.

Let us dwell on aphid relationships with numerous natural populations of entomophages, in particular predators. Aphids are developing on all parts of fruit trees: on leaves, flowers, fruits, bark of trunks, branches and roots. Most species inhabit on leaves and young not stiff shoots. The leaves are twisting, deformed, changed colour, prematurely withered and showered in case of mass settlement. Damaged leaves lag behind in growth strongly. Often they are covering completely with sugar secretions and larval skin of aphids, on which developed sooty fungi. As result, the leaves lose their ability to assimilation.

Young not stiff shoots, which covered with colonies of aphid, develop abnormally and become curved. As result, their winter hardiness is decreasing. As our researches have shown, shoots are damaged especially strongly such species as dysaphis reamuri, green apple aphid and rosy (apple) aphid. We have established that the settlement by aphids on fruits of pome cultures in the exclusion zone was not observed. At that time such species as rosy (apple) aphid, rosy leaf-curling aphid and dysaphis reamuri are populated immature fruits in industrial gardens. Also in industrial gardens was noted intense colonization by dysaphis reamuri, apple-grass (oat-apple) aphid and rosy (apple) aphid on flowers and pedicels. Main factor preventing settlement of aphids on reproductive organs of pome fruit cultures is activity of population of entomophages, especially predators, which concentrated on flowers.

Condition of forage plant, weather conditions, activity of entomophages were affected on dynamic of strength of aphids. There are predators, parasites and entomopathogens among natural enemies of aphids. In ecosystems of the exclusion zone predatory insects dominated - Coccinellidae, Syrphidae, Cecidomyiidae and Chrysopidae. The parasites of aphids - Aphidiidae (aphidophages) were met sporadically. Long-term researches by authors showed that in spite of various synoptic anomalies and other stress factors were observed practically no mass outbreaks of aphids in perennial woody plants of the exclusion zone.

The process of asynchronous development of aphids and entomophages during the reactivation of entomocomplex in early spring was observed annually. Usually, the increase of strength of all aphid species, which inhabited on leaves and young shoots, was observed in spring. The quantity and species diversity of population of predatory insects was increased only after 10-13 days.

The well-known regularity about basic regulatory role of polyphagous entomophages at low strength of population of aphids was confirmed (Дорохова идр., 1989). The value of specialized 
entomophages is increasing with strength of aphids. It is essential that the capacity of environment almost never was close to saturation in the exclusion zone. It means that mechanisms of intraspecific competition for feed were excluded. In period of increasing of strength of aphid populations were activated entomophage populations proportionally. In this case, the level of strength and intensity of parasitism and predation of entomophages was determined by functional and numerical reaction of parasites to growth of density of hosts. Functional reaction denotes increasing in the number of hosts, infected by one individual of parasite. Numerical reaction is concentration of parasites in places of accumulation of hosts, as well as the growth of strength of entomophages in subsequent generations (Solomon, 1949; Гурьянова, 1977, 1978, 1984; Дрозда, 2015а). The phenomenon of functional and aggregative reaction is determined genetically, but with significant reaction rate.

The researches of Holling (1959) were showed presence of three types of functional reaction. The first type is characterized that the quantity of victims with growth their density increases linearly, then breaks off abruptly and exits to plateau. The second type of functional reaction is curvilinear rapid increase by quantity of victims with gradual slowdown. The third regularity is manifested in sigmoid form. The second type of functional reaction is considered universal for parasitic species (Holling, 1959a). Practically all three types of functional reaction were confirmed experimentally by our researches in population of aphids and entomophages in ecosystems of the exclusion zone.

Ecological and physiological essence of this phenomenon determines level of regulatory and modifying role of entomophages. Significant is the fact that population and individual stability of aphids in relation to entomophages was shown distinctly. Usually, effective part is from 20.8 to $35.4 \%$ of aphid populations of the composition of each species.

These are highly viable individuals, which practically were not populated by entomophages. The trophic substrate of entomophages is physiologically weak part of aphids. This is pronounced in relation to predators especially distinctly. The predators destroy them almost completely. A somewhat different regularity is manifested in relationships of aphids and Aphidiidae, Aphelinidae. The females of these parasites, especially physiologically motivated, cut off $17.4-22.5 \%$ of effective part of population of aphids, while exhibiting elements of regulatory role.

Coccinellidae feed exclusively on aphids of Homoptera: Adalia decempunctata L., Adalia bipunctata L., Calvia quatuordecimguttata L., Halyzia sedecimguttata L., Scymnus ater Kug., Scymnus auritus Thund., Scymnus rubromaculatus Gz., Scymnus subvillosus Gz., Synharmovia conglobata L., Synharmovia lyncea A. Ol., Coccinella septempunctata L. and other. The ecosystems of the exclusion zone have visited more than 30 species of ladybirds facultatively or continuously.

Syrphidae (Diptera) are playing significant role in reducing strength of aphids. The speed of development, high voracity and great fertility makes it possible to attribute of Syrphidae with Coccinellidae to the number of very effective aphidophages. Among other predators should be noted gall midges (family Cecidomyiidae). Larvae of Aphidoletes aphidimyza R. are unspecialized aphidophages. They use more than 60 species of aphids, mostly fruit. One larva destroys from 35 to 90 aphid individuals during period of his development. The family of Chamaemyiidae was noted also. The larvae of this family feed on many aphids. Chamaemyiidae give 3 to 4 generations during year. Among the predators of garden phytophages differs family of Chrysopidae by strength and quantity of species. They occupy 3-4 places. The larvae were distinguished by polyphagia and voracity. The larva destroys 250 to 500 aphids during her development. Chrysopa carnea Steph. is received most widespread in ecosystems of the exclusion zone. 


\section{Conclusions}

As result of experimental researches 9 species of aphids were identified on plants of family Rosáceae in the exclusion zone of the Chernobyl nuclear power plant. Most of them were exposed to r-selection and characterized by high strength and harmfulness. The character and specificity of plant colonization by aphids, their specialization in relation to different organs and high level of harmfulness were established. Ecologically and trophically with aphid populations is associated significant quantity of entomophages - parasites and predators: Aphelinidae and Aphidiidae. The character of trophic interactions between aphids and their entomophages was investigated. Three types of functional reaction in the «aphids-aphidophages» system were established. The modifying role of aphidophages in dynamic of strength of aphid populations was shown. Parasitic Aphidiidae is manifested elements of regulatory role sporadically, parasitizing on insignificant part of effective population of aphids. The most significant representatives of predatory arthropods, which ecologically and trophically associated with aphid populations on woody plants in the exclusion zone of the Chernobyl nuclear power plant, were shown.

\section{References}

Holling, C.S. 1959. Some characteristics of simple types of predation and parasitism. Canad. Entomol., vol. 91, no. 7, p. 385-398.

Holling, C.S. 1959a. The components of predation as revealed by a study of small mammal predation of the European pine sawfly. Canad. Entomol., vol. 91, no. 7, p. 293-320.

Solomon, M.E. 1949. The natural control of animal populations. J. Anim. Ecol., vol. 18, no. 1, p. 1-35.

Адашкевич, Б.П. 1975. Энтомофаги вредителей овощных культур. Афидофаги. М., Колос. 190 с.

Варли, К., Градуэлл, Дж. Р., Хассел, М.П. 1978. Экология популяций насекомых. М., Колос. 222 с.

Гурьянова, Т.М. 1977. Реакции Nemosturmia amoena (Diptera, Tchinidae) на плотность популяции сосновой совки (Panolis flammea). Зоол. журн., т. 56, № 1, с. 72-78.

Гурьянова, Т.М. 1978. Адаптивное поведение Exenterus abruptorius Thunb. (Hymenoptera, Ichneumonidae) и ее функциональная реакция на плотность популяции хозяина Neodipron sertifer Geoffr. (Hymenoptera, Ichneumonidae). ДАН СССР, т. 240, № 6, с. 1493-1496.

Гурьянова, Т.М. 1984. Поведенческие механизмы взаимоотношений у паразитов-энтомофагов с хозяинами и регуляция численности насекомых. Сб. Поведение насекомых. М., Наука. с. 95-118.

Дорохова, Г.И., Карелин, В.Д., Кирияк, И.Г. 1989. Полезная фауна плодового сада. Справочник. М., Агропромиздат, 319 с.

Дрозда, В.Ф., Гойчук, А.Ф. 2015. Біорізноманіття лісових екосистем та біологічний захист дібров від лускокрилих фітофагів. Міжнародна конференція «/нноваційний розвиток АПК України: проблеми та їх вирішення». Житомир. с. 201-205.

Дрозда, В.Ф. 2015а. Біорізноманіття, як функція стійкості екосистем: теоретичні аспекти проблеми. Міжнародна наукова конференція «Інтегрований захист та карантин рослин. Перспективи розвитку в ХХІ столітті». Київ, НУБіП, с. 198-200.

Дрозда, В.Ф., Сагитов, А.О. 20156. Характеристики жизненных стратегий карпофагов в контексте защиты садов в условиях Украины и Казахстана. Международная научная конференция «Инновационные экологически безопасные технологии защиты растений». Казахстан, Алматы, С. 98-108.

Дядечко, Н.П. 1978. Сохранение и использование энтомофагов в агроценозах. Защита растений, вып. 2, с. 22-23.

Колесова, Д.А. 1979. Борьба с тлями в плодовом саду. Воронеж. ЦЧКИ. 52 с.

Лахидов, А.И. 1978. Яблонные тли. Обзор развития вредителей и болезней сельскохозяйственных 
культур в 1978 г. и прогноз их появления в 1979 г. в Воронежской области и меры борьбы с ними. Воронеж. с. 40-41.

Скуфьин, К.В., Зимина, Л.В., Переяславцева, А.Б. 1962. Материалы по фауне сирфид (Diptera, Syrphidae) Воронежской области в связи с их значением как ландшафтных насекомых. Воронеж. Охрана природы ЦЧП, т. 4, с. 165-173.

Стадницкий, Г.В., Бортник, А.М. 1979. Энтомологические проблемы защиты таежных лесов. Изд. вузов. Лесн. журн., № 3, с. 5-13.

Теленга, Н.А. 1959. Пути реализации химической борьбы с вредителями в направлении сохранения полезных энтомофагов. Киев. Науч. тр. Украинского НИИзР, т. 8, с. 87-96.

Яснош, В.А. 1975. Афелиниды. Защита растений, № 3, с. 40-42.

Яснош, В.А. 1975а. Трофические связи и поведение афелинид (Hymenoptera, Aphelinidae). Сб. Поведение насекомых как основа для разработки мер борьбы с вредителями сельского и лесного хозяйства. Институт зоологии АН УССР, с. 207-213. 